\title{
The architecture of the Nałęczów Nursery in the context of designing kindergarten and care facilities
}

\author{
Natalia Przesmycka, \\ https://orcid.org/0000-0002-1755-2448 \\ n.przesmycka@pollub.pl \\ Department of Architecture, Urban and Spatial Planning, Faculty of Civil \\ Engineering and Architecture, Lublin University of Technology
}

\section{Kamila Lucyna Boguszewska}

https://orcid.org/0000-0002-1513-2490

k.boguszewska@pollub.pl

Samodzielna Pracownia Architektoniczna, Wydział Budownictwa i Architektury, Politechnika Lubelska

\begin{abstract}
Summary: The article presents the history and architecture of the nursery building in Nałęczów, one of the first buildings of this type erected in rural areas of the Lublin region. This building escapes the clear stylistic classification and is an inseparable element of the cultural landscape of Nałęczów.

In an attempt to determine the implementation of the Nałęczów project in comparison with other shelters created in a similar period of time, this paper takes a broader look at the problems of establishing the institution of nurseries and later transformations of such objects.
\end{abstract}

Keywords: Nałęczów, nurseries architecture, Nursery's building, Jan Witkiewicz-Koszczyc

Beautiful school hill. At the front of the square, just behind the road, a beautiful brick house rises. Walls made of grey stone jointed with cement, roof's strong line broken with protruding small windows and balconies, veranda supported by arched arcades. Mighty escarpments contain the building; thick wall surrounds the square from the side of the road. ${ }^{1}$

The Nursery in Nałęczów is one of the oldest buildings designed specifically for care and education of the youngest children in Poland. Additionally the building's form and programme is considered to be superior to similar facilities located in other Polish cities or villages.

\section{Current state of research and methodology, literature review}

Research of Nałęczów's architecture, including the Nursery's building, is inhibited by the small amount of source materials such as preserved architectural projects. Building development in Nałęczów concentrated in the area administered by the Medicinal Institute. There was no need to obtain building permits through a regular project approval process, hence the lack of archival documentation. Nałęczów's Nursery, as one of the buildings 
designed by architect Jan Witkiewicz-Koszczyc, was included in a monographic study of the designer's work by M. Leśniakowska (Leśniakowska, 1998).

Authors' research and results are based in literature studies on the subject, including compilations from the period when Nursing facilities forms were formulated (the end of the $19^{\text {th }}$ century), iconographic analysis, queries in the archives of WUOZ (Voivoidship's Office for Heritage Preservation) in Lublin and authors' own field research.

This paper presents a comparative analysis of nursing facilities built at the turn of the $19^{\text {th }}$ and $20^{\text {th }}$ century in the area of present-day Poland (30 objects). The analysis took into consideration the composition of the architectural form, location in the spatial structure of the urban area, the state of preservation and contemporary role and use.

\section{Care facilities for the youngest - function's origins}

Analyzing the architectural form of nursing facilities, it should be noted that its formation was sparked by the emergence of a demand for such a new function. Existing care facilities were dedicated primarily to adults: the elderly, the poor and the handicapped, their operation was often tied with charitable activities of the Catholic Church in Poland.

The institution of nurseries, which, over time, developed into modern kindergartens, became popular in the $19^{\text {th }}$ century. The movement involved with small children's nursing schools has developed intensively in the British Isles, France and Germany. In 1817 in the industrial settlement of New Lanark in Scotland, its owner Robert Owen, gathered 150 children aged 2 to 7 years under the care of one of the weavers - John Buchman. The children were looked after while their mothers were at work. The so called Infants Schools developed further both as institutions and teaching methods. The intensive development of nurseries also took place between 1890 and 1923 in the United States where, together with other forms of charity institutions, their formation became an inseparable element of civic duties.

The first nursery in the Kingdom of Poland was established in Warsaw as the initiative of Teofil Janikowski, a member of the Charitable Society (Towarzystwo Dobroczynności), in 1840, and within the next 9 years the number of Warsaw nurseries increased to eight. ${ }^{2}$ In the early years of functioning, the employees in these nurseries were exclusively men, but in a short time this occupation became the domain of women. ${ }^{3}$ Simultaneously, religious organisations and religious orders also started to create nurseries.

The first nursery in Silesia was established in Opava by the Sisters of the Third Order of St. Francis in June 1849, initially accepting 60 children. Karol Antoniewicz describes it the following way:

"In the town of Freuwaldau, in Silesia, at the foot of the Grafenburg Mountain, world-famous for Priessnitz's water treatment, there is a small, slim house on an outside street. Enter this house if you are sad, your heart is heavy, and you will be comforted if you have the faith and love of God and people in your heart! (...) a children next to each other develop in work and prayer! (...) Children learn to mend, stich, pray and love God, covered from the evil influence of corruption, who left to themselves, living the street life, would inevitably die, both physically and eternally!" ${ }^{4}$

The nursery was a modestly equipped building - in one room there was a table, "several benches for children, a few pictures and a little stoop and a moneybox for charity donations, visiting the nursery". The institution had a religious character, according to the belief that prayer can save from corruption and demoralisation.

3 Cieślińska B., Kształcenie nauczycieli przedszkoli w Polsce w wymiarze instytucjonalnym, „Rocznik Towarzystwa Naukowego Płockiego”, 2017, nr 9, p. 510.

4 Antoniewicz K, Ochronka, 1849, N. Piekary: T. Henetzek 
In the second half of the $19^{\text {th }}$ century the forms of pre-school institutions were diversified; urban, rural, factory nurseries as well as children's gardens were created, whose functioning was closest to that of modern kindergarten. In larger cities the so-called Fröbel's gardens (Friedrich Froebel Approach) began to be organized, which, in contrast to the nurseries, were targeted at children of wealthier classes, preparing them for later school education. The nursing facilities supervisory function gradually evolved in favour of care and educational functions, conducted by professional societies. ${ }^{5}$

With time, the nurseries begun to be established in village areas as well, where they had a different character from those functioning in cities. The aim of rural nurseries was not to change the way rural children were formed, nor was their education. These nurseries were supposed to "protect the body and soul of a village child; to teach the Lord's Prayer as well as the first principles of faith and morality" and "to awaken minds with skillful conversation, work and play" (p. 19). For this reason, nurseries for rural children operated differently from those for urban children. Rural nurseries were primarily intended to help bring up the youngest children from the poorest families, relieving their working mothers. ${ }^{6}$ Helping villagers to raise their offspring was considered to be the duty of the "higher classes". There was a close relation between the way the child was brought up in the countryside and its future role in society, shaping its character and health (through hardening) to perform heavy physical work from an early age (p. 10). By the age of seven or eight, the child "can be of help around the house only temporarily and to a very limited extent", at the ages of eight and ten, children's help with farm work began to be effective, and later they quickly became coworkers. The difficulty of farm work was dosed with age: from helping with picking forest fruits, mushrooms, peeling potatoes, bringing food to field workers, taking care of animals (herding), simple field work (guiding a horse while harrowing, helping with harvest), to the most demanding ones - i.e. operating sokha or plough, which boys usually mastered at the age of about 19 , which was also the time of finding a mate and getting married.

The enfranchisement of peasants (1864) resulted in a change in socio-economic relations in the countryside. Charity institutions were to be moved from parish custody to communal management. However, the commune boards were not interested in the organization of nurseries, nor did they have at their disposal the means to do so.

It was particularly important to organize nurseries for children of the farm workers. Among the functional and accommodation guidelines for the nursery facility, the dominant belief was that their standard should be appropriate to the level of wealth of the families from which the children came and to not exceed it in any way, so as not to "arouse the whims towards the position and wealth of parents". ${ }^{7}$ The cleanliness of the interior, the modesty and functionality of the equipment, the heating capacity ("it is good to instal the fireplace next to the stove"), good lighting, the floor made of boards and the possibility of opening windows (vents), were mandatory requirements for the building or room of the nursery. The children had to be provided with appropriate low benches, while the nurse had to be provided with a desk with a drawer and several chairs. Altar was an obligatory element of decor, the function of which could also be performed by a table covered with a cloth and placed by the wall. ${ }^{8}$ The nursery's equipment for playing and learning indicated in the nineteenth-century handbooks were sand trays, chalkboards and abacuses but still the most important were the wallboards with religious inscriptions.

Educational and pedagogical ideas were developed in intelligentsia social circles. Helping people from lower social classes was also one of the determinants of the patriotic civic stance. Many eminent contemporary intellectuals, educators and creators were concerned with the problems of early education and upbringing, physical condition and health of children. Many of whom were visiting Nałęczów, as the popular health resort at the turn of the $19^{\text {th }}$ and $20^{\text {th }}$ century. The particular development of education in Nałęczów was influenced by such personalities as: Bolesław Prus, ${ }^{9}$ Stefan Żeromski, Faustyna Morzycka, and, above all, members of the "Światło" Educational Society.

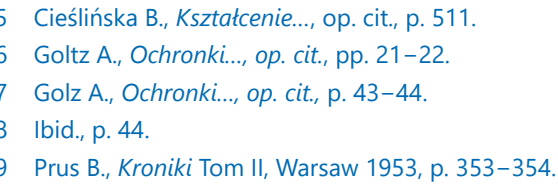




\section{Nałęczów Nursery - rise of an institution}

Attention to education and improvement of qualifications and living standards of the inhabitants of Nałęczów and nearby area was an expression of the positivist movement which characterised the health resort's development at the turn of the century. In 1903 the School of Basketry Instructors was established, and two years later the J. Bloch Toy Maker Instructors School. In 1904 a public bathhouse was opened - the Bolesław Prus People's Baths. At the same time, on the initiative of doctors: Lasocki, Malewski and Puławski, the Museum of the Lublin Region was established. ${ }^{10}$ In 1906 the People's House (Ludowiec) was established, where agricultural associations Zgoda and Nałęczów Credit Society (so called Kasa) found their seat. ${ }^{11}$ In 1908, the Museum of the Lublin Region, where regional and ethnographic collections were displayed, was relocated from the Małachowski Palace.

At the turn of $1907 / 1908$ the first round of 6 -month courses for peasants took place - in a school that has been operating since then in the People's House. ${ }^{12}$ Since 1908 the schools have been known under the common name Szkoła Instruktorów Przemysłu Ludowego (School of People's Industry Instructors). At the same time, the Female Farming School was established. In 1911 the School of Wood Industry was established, a year later, under the direction of Jan Żylski, the School of Wood Sculpture Instructors was established. Jan Żylski continued his activity in the field of education also after World War II, together with Mieczysław Pazura, initiating in 1947 the creation of the Secondary School of Fine Art Techniques, which still exists today. ${ }^{13}$

The schools of Nałęczów are still a phenomenon on a national scale. In a small private town before World War II there were a number of educational institutions with a diverse offer. One of them was the Nursery established at the beginning of the $20^{\text {th }}$ century.

\section{Main objectives and tasks of the "Światło" Educational Society}

The Educational Society "Światło" was established in Nałęczów in $1906 .{ }^{14}$ It's establishment was a resut of the activity of educated and progressive people such as Stefan Żeromski, Gustaw Daniłowski or Faustyna Morzycka. Officially, in August 1906 "Światło" was registered with associations and unions for the Lublin Governorate. Its main objective was to provide educational and cultural activities for the benefit of fellow citizens.

"Światło" operated without the support from the state - it was a grassroots organization. It's motto was "People's education is a debt owed by the enlightened circles to the whole of the nation" together with a belief that "the prosperity of the nation and the whole country" rests upon them. Each member of the Society was obliged to work in "one of its departments" and should "in cultural matters renounce all political, party or social considerations." ${ }^{115}$

"Światło" organized courses for illiterate peasants, created a system of primary education and Polish textbooks for people. ${ }^{16}$ Educational programmes were developed to supplement and deepen the already acquired education - agricultural courses (School of Female Landowners, Courses for Peasants, etc.). ${ }^{17}$ There was a

10 Puławski A., Materiały do historii zakładu Leczniczego w Nałęczowie (1807-1907), Nałęczów 1908, s. 29

11 Stanisław Śliwiński, the owner of the Antopole estate since 1895, played an important role in the shaping of various social undertakings and agricultural education in Nałęczów. He was the initiator of the agricultural association Zgoda, a dairy company, one of the founders of the Nałęczów Credit Society, an agricultural school for landowners. Przegaliński A, W kręgu Stanisława Sliwińskiego i nałęczowskiej oświaty rolniczej na przetomie XIX i XX wieku, "Rocznik Lubelski" 35, 139-154, 2009, s. 143-150.

12 Ibidem, pp. 149-150.

13110 lat Liceum Plastycznego im. Józefa Chełmońskiego w Nałęczowie, wyd. Petit na zlecenie, Liceum Plastycznego im. Józefa Chełmońskiego w Nałęczowie, red. P. Kmieć, Ł. Głowacki, K. Rządowski, J. Ćwiek, Lublin 2013.

14 Initially, in 1906, in Nałęczów there was a School Matrix Circle, founded by Stefan Żeromski, which was a branch of the School Matrix in Warsaw. M. Gawarecka, Lubelskie Towarzystwo szerzenia oświaty pod nazwa "Światło" (1906 - 1917), Rocznik Lubelski 16, 1973, pp. 183-186.

15 M. Biernacki, Cel i zadania Światta, [in:] Zebranie organizacyjne Lubelskiego Towarz. Szerzenia Oświaty p. n. „Światło” odbyte w Lublinie w dniu 23 września 1906 roku, nakład Towarzystwo Światło, 1906, Lublin, pp. 4-10.

16 The question of setting up nurseries, as these require a lot of capital and teaching staff resources. Naturally, something can be achieved with the help of municipalities and towns. "Światto" will create, besides home teaching of reading and writing, at least a small number, but exemplary, of schools according to the new rules and programmes, in order to prepare the material and an example for those nurseries, which will later undoubtedly create self-government or autonomy. M. Biernacki, Cel i zadania Światła, [w:] Zebranie organizacyjne Lubelskiego Towarz. Szerzenia Oświaty p. n. "Swiatło" odbyte w Lublinie w dniu 23 września 1906 roku, nakład Towarzystwo Światto, 1906, Lublin, pp. 4-10.

17 M. Gawarecka, Lubelskie..., op. cit., pp. 183-186. 
theatre and the People's University ${ }^{18}$, which during its functioning (10 December 1905 - 22 November 1907) organized 65 talks and lectures ${ }^{19}$. All the initiatives needed accommodation. For this purpose, model nurseries, people's houses, libraries, schools of various levels and teacher seminars were opened. ${ }^{20}$ One such buildings is the Nałęczów Nursery. Originally, the Nursery, like many similar institutions, found its place in a building not designed for this specific purpose - in the Józefinka villa. From 1905 it was located in the Octavia villa, except during the summer period, when the rooms of the Octavia villa were rented to the sanatorium patients, and the Nursery functioned in a nearby building. Later it was moved to a villa rented from Mr Trojanowski. ${ }^{21}$ The building of the Nursery, also known as the "House of Light" (Dom Światła) was erected on commission from Stefan Żeromski.

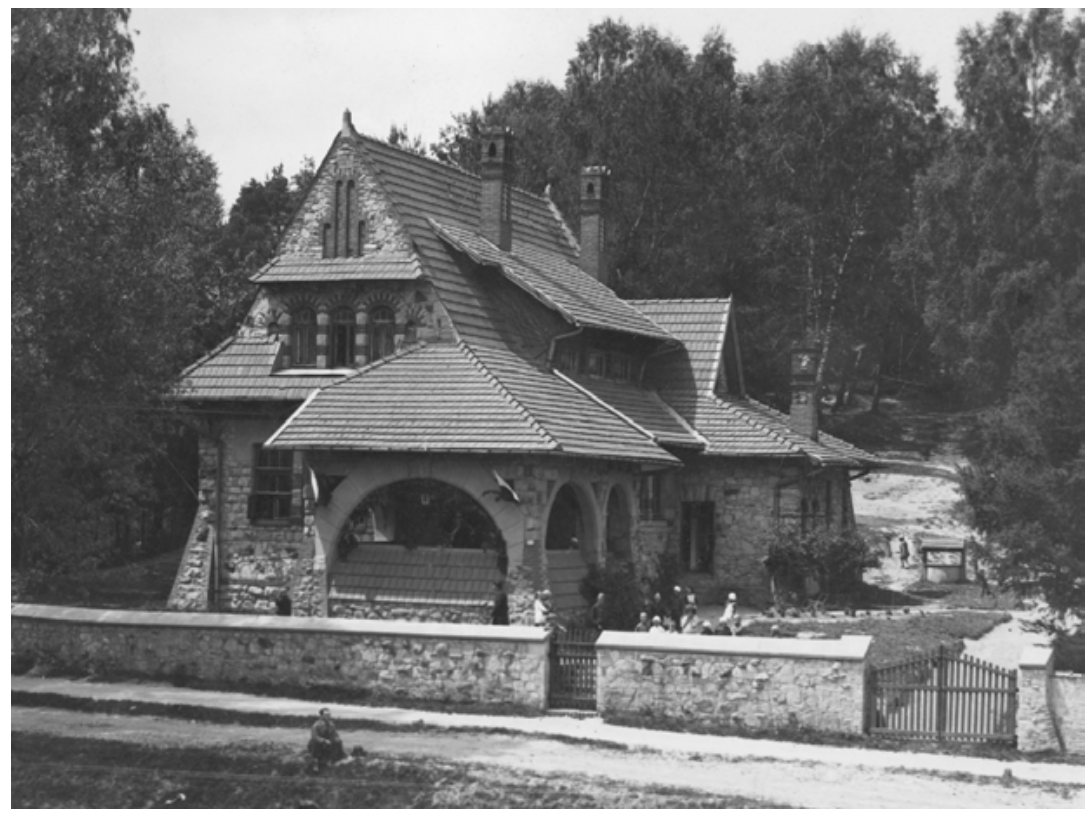

Fig. 1. The Adaś Żeromski Nursery, circa 1928, source: National Digital Archives

This was associated with the writer's initiative to open the aforementioned People's University, which was inaugurated on the $75^{\text {th }}$ anniversary of the November Uprising, ${ }^{22}$ and the need to create a nursery for the children of craftsmen and farm workers. ${ }^{23}$ The building was built in $1906^{24}$ it was designed free of charge by Jan Witkiewicz-Koszczyc. ${ }^{25}$ Funds for the construction of the Nursery came mostly from Stefan Żeromski (honorarium for his novels "The Wages of Sin" and "Ashes"), as well as from community contributions and a book published in order to obtain funds under the title "For a new school". ${ }^{26}$

Stefan Żeromski was very invested in the project - he himself ordered roof tiles and other materials. The final construction cost was estimated as follows: - Masonry work amounted to one and a half thousand roubles,

18 The People University in Natęczów (...) must try to make the students interested with the help of loose lectures. Slowly a systematic course is being organized (...) M. Biernacki, Cel $i$ zadania..., op. cit., pp. 4-10.

19 M. Mironowicz - Panek, Działalność lubelskiego Towarzystwa Oświatowego „Światło” w: Ziemiaństwo na Lubelszczyźnie, p. 362

20 M. Gawarecka, Lubelskie...op. cit., pp. 183-186.

21 S. Butryn, Nałęczów wspomnienia o Żeromskim i goście kurorttu, Wydawnictwo Pro - Info, Lublin 2011, pp. 27-28

22 M. Mironowicz - Panek, Działalność... op. cit., p. 362.

23 S. Butryn, Natęczów...op. cit., pp. $28-29$.

24 M. Leśniakowska, Architect Jan Koszczyc Witkiewicz (1881-1958) and building in his time, Warsaw 1998, p. 163.

25 In 1906 I was in a Pawiak prison, when Żeromski came to me to design him a building as an exemplary nursing school. After I was released from prison, I started building. After its construction, it housed a nursery, a secret school, a meeting place of "Światło", a library. I would like to mention, by the way, that Stefan Żeromski gave over 6000 roubles for the construction of the nursery. At that time, I remember, under the influence of Żeromski, we carried out social and political work in Nałęczów, S. Butryn, Natęczów...op. cit., pp. 50.

26 M. Mironowicz-Panek, Działalność lubelskiego Towarzystwa Oświatowego "Światło" w: Ziemiaństwo na Lubelszczyźnie, p. 362 
wood - about a thousand roubles, and ceramic roofing tile 355 roubles $^{27}$. The building of the Nursery was erected by local builders: Łuka, Lenartowicz, Oreszczyński, Krajewski and Pakuła. ${ }^{28}$

The Nursery building was located on a plot purchased by Stefan Żeromski from Michał Górski near the Poniatówka Hill at Poniatowski Street (Fig. 1). The area of the plot was nearly $3,000 \mathrm{~m}^{2}$ and sloping to the east. The difference in altitude was quite significant and originally amounted to 13 meters. The building is located in the eastern part of the plot right next to Poniatowski Street. The Nursery building has been very well adapted to the surrounding area, using the plot's difficult topography. The building was separated from the street by a stone fence - a retaining wall, which was erected in $1909 .{ }^{29}$ On a postcard from that time you can see that the limestone wall separating the plot was also located on the northern side of the plot. The garden was arranged to form a landscape - plants were planted in groups and the geometry of the walking path was designed to resemble an English garden. Due to the terrain's requirements, terraces were used in the Nursery's garden. Dancing squares and sand playgrounds surrounded by turf benches were located in the central part of the garden. The garden was planted with pines, groups of birches and also had a field for vegetable plant farming.30 Behind the Nursery's building, facing the garden, there was a dugout cellar hidden in the slope of the escarpment.

The usable area of the Nursery building was $130 \mathrm{~m}^{2}$ and was intended for about forty children. ${ }^{31}$ The building served primarily the children of farmers from the surrounding villages: Charza, Bochotnica, Strzelec, as well as the children of employees of the Medicinal Institute and staff from private villas. ${ }^{32}$ The Nursery was built of limestone and ceramic brick, which were fashioned into architectural decorations, such as, among others: window frames - arches of windows, blind windows, etc. The Nursery's Designer Jan Witkiewicz-Koszczyc applied a characteristic arrangement of bricks (alternating the stretcher and header sides of bricks) contrasting with the white limestone, a solution often repeated in other public buildings erected in Nałęczów at that time. The form of the Nursery referred to the national style popular in Polish architecture in the first quarter of the $20^{\text {th }}$ century. ${ }^{33}$

The single-storey building, supported by a brick foundation, has a utility attic and basement. The body of the Nursery has been covered with a steep, multi-sloped roof with various angles of inclination, which line broken with protruding small windows and balconies, covered with ceramic tiles. The top of the eastern front elevation was emphasized with blind windows, crowned with a rectangular plaque with the year 1906 and a thistle branch - the symbol of Young Poland and an inscription Jan Witkiewicz-Koszczyc. The characteristic element of the building is the veranda on the side of Poniatowski Street (eastern front facade), which was supported by quadrangular columns reinforced with buttresses and wide arcades.

The building was supposed to evoke a feeling of "cosiness" - provide a sense of security and shelter. This effect was achieved by the use of protruding hoods and characteristic curves. Thanks to this, the architecture of the building has gained a "fairy tale, childlike element." The architectural detail characteristic to the design of Witkiewicz's Nursery, which was present in the building's body, both inside and outside, was a pinnacle, in the form of a geometrised flower bud, crowning the tops of the facade and repeated inside, in the staircase balustrade's detail.

Functionally, the building consisted of a vestibule (veranda), cloakroom and a spacious hall which had the capacity to be separated into two smaller rooms (Fig. 2). The institution's facilities were a small kitchen located in the eastern part with a warehouse and a toilet. This part of the building could be entered by a separate entrance. The rest of the internal area was dedicated to communication, children's toilets and a boiler room. The main hall was decorated with oil paintings by Kazimierz Młodziankowski in the form of a wall frieze, depicting

27 S. Butryn, Natęczów... op. cit p. 28

28 Ibidem.

29 Such information is included in the white card of the WUOZ attachment 5 "Nursery's fence Poniatowski St. 33, M. Leśniakowska cites 1913 as the date of erecting the stone fence, M. Leśniakowska, Architekt Jan Koszczyc Witkiewicz (1881-1958) i budowanie w jego czasach Warszawa 1998, p. 163

30 S. Żeromski, Róża, 1909, p. 205

31 Reports from 1907-1909 have not survived to date, which means that we are not able to determine precisely the number of children attending the Nursery during this period of time. In 1909/1910 there were 82 children enrolled in the Nursery and 40 children attended classes. The library operating in the institution numbered 380 books at that time. Za: S. Butryn, Natęczów..., op. cit., p. 30.

32 S. Butryn., Natęczów...op. cit. s. 35.

33 M Lesniakowska classifies the Nursery building as an example of Zakopane style architecture. The author states that this is the first attempt to translate the Zakopane style into a material other than wood. M. Leśniakowska, Architekt..., op. cit., p. 30. 
the Vistula Landscape and the allegory of human life. The paintings were to be inspired by paintings in the Paris's Pantheon. They were made free of charge in 1910. The costs of canvas and paints were covered by the Żeromski family. ${ }^{34}$
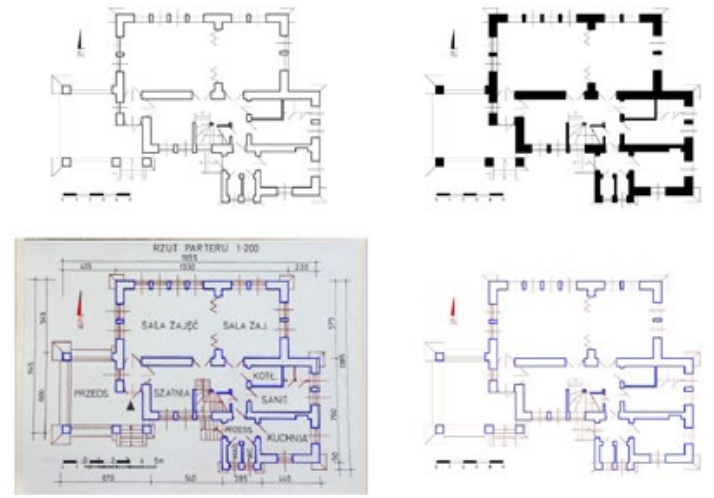

Fig. 2. Schematic plan of the Nursery, current state, (archive of KAUiPP),
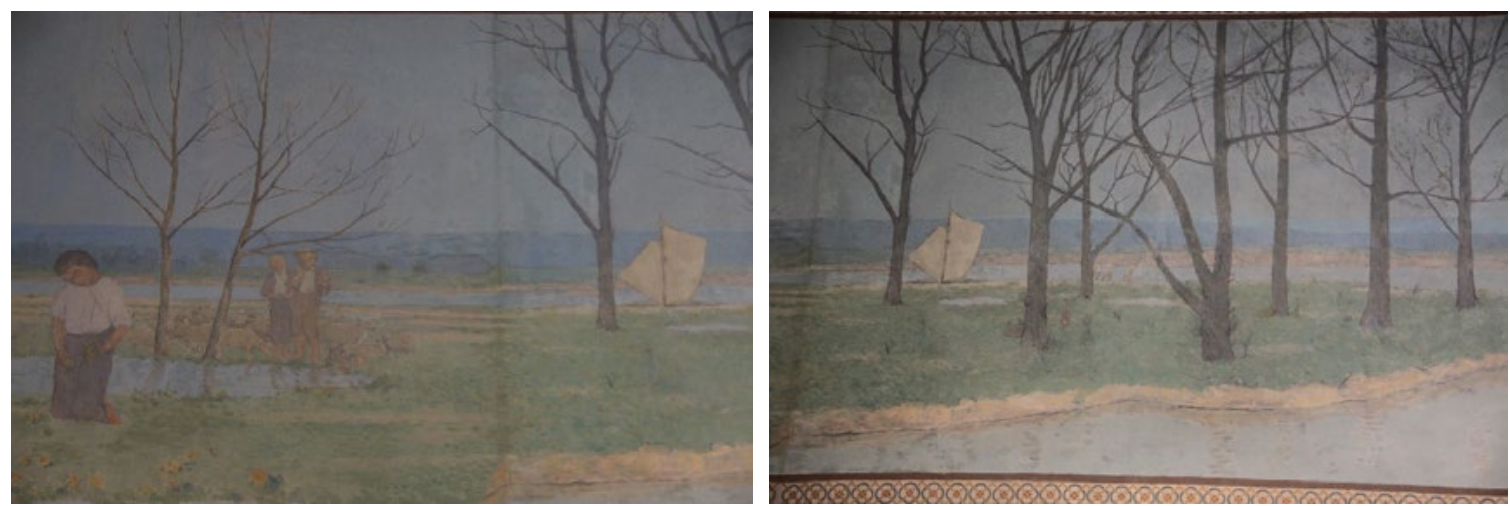

Fig. 4. Fragment of the Vistula Landscape by Kazimierz Młodzianowski, photo by authors 2018.

The building together with the Jordan's garden was put into use on 19.07.1907. Stefan Żeromski, Oktawia Żeromska and Henryka Witkiewicz took custody of the building. Due to financing problems of the institution, in 1915 the Nursery and the school were closed down. During the war, soldiers were stationed in the Nursery and it was only after their departure that it resumed its activity. In 1918, with the consent of the founder of the facility, the Nursery received the name "Adam Żeromski Nursery" in honour of the Stefan Żeromski's deceased son. Jan Witkiewicz-Koszczyc, its designer, was responsible for the conservation of the building from 1908 for nearly forty years (after the war) as an employee of the General Directorate of Museums and Heritage Protection.

In 1920 Stefan Żeromski handed the Nursery over to the Government of the Republic of Poland ${ }^{35}$ at whose expense the renovation was carried out. Since then, the Nursery has become the property of the state and has become the oldest state kindergarten in Poland. 
After regaining independence, an attempt was made to regulate the organisation of pre-school education institutions at the First National Teachers' Congress in 1919. The Kindergarten Education Section was established, which presented an outline for functioning of these institutions. ${ }^{36}$

\section{Nałęczów Nursery, its architecture and fate in the context of other nurseries}

The nurseries created in the same period of time on the territory of present-day Poland had various architectural forms. Their size and presence depended on the financial capabilities of the founders, which were most often Catholic Church institutions (such as monasteries), private entrepreneurs and landowners. Nurseries dedicated to the children of industrial workers were most often in an architectural form consistent in style with the one of the neighbouring factory plants, their design was entrusted to recognized architects. (e.g. a 1912 nursery for working children funded by Anna Scheibler in Łódź, designed by Hans Schlicht, or in Żyrardów (1875), designed by Franz Lessner).

The Nałęczów Nursery was established at a similar time to the St. Joseph's Nursery in Rymanów (1902) run by The Little Servants of Mary Immaculate Sisters (Old Town), often referred to as "Nursing Sisters". This congregation was founded by Blessed Fr. Bojanowski, who was one of the initiators of the establishment of the nursery for children, seeing in them, first of all, the tools of moral education, without neglecting physical and mental development. It is also worth emphasizing the importance of bringing up children in the spirit of national tradition and language. ${ }^{37}$ The nursery's building was erected on the land donated by Countess Anna Potocki. Local residents and priests helped to finance the investment. In the first years it functioned mainly thanks to grants from Fr. Koleński and Fr. Federkiewicz and the Count Potocki. Before the war, 200 children were nursed here. The destruction of World War I affected Rymanów and did not spare the Nursery. ${ }^{38}$ The building still functions as a kindergarten today. The architectural form of the building has not changed.

Many nursery buildings have not survived to this day with the Second World War being the turning point. At that time, the Germans liquidated practically all nurseries and orphanages for Jewish children, which usually involved killing of the children who were under the care of these institutions and their nurses. Private nurseries, which were part of the land estates, whose owners disappeared, were destroyed and dismantled. This was the fate of Ignacy Paderewski's Nursery in Kąśna near Cracow, which was established thanks to the initiative of Ignacy Paderewski's foundation.

Poor technical condition, lack of possibility or idea how to adapt to modern needs has lead to the demolition of the nurseries in Kolno and Lubcza in recent years. The Lubcza nursery was established on the initiative of Father Józef Lenartowicz. ${ }^{39}$ The building had characteristic neo-Gothic decorations - a toothed gable, sharpedged blind windows and a bell tower. As part of the revitalisation programme project, a modernised municipal facility with socio-cultural functions 40 was to be established there. Unfortunately, the building of the former nursery was demolished in January 2018; however its oldest part with a characteristic turret is to be reconstructed.

Built in 1919, the nursery for war orphans, located in the center of Kolno, was demolished in March 2014. A shopping centre was built in its place, which in no way reflects the previous form of development. In the year of its construction the Presidential Oak of Freedom was planted on the axis of the main entrance. The architectural form of the building invokes the regional characteristics of development through a jerkinhead roof and the decorative use of wood - decorating the gable emphasizing the entrance to the building, or roofing over the side entrance supported by carved columns.

Some of the former nurseries after World War II functioned as kindergartens (Pleszew, Węglin, Żyrardów), or facilities for orphaned children. Among the best preserved are the buildings founded by monasteries, that did not change their ownership (Rymanów, Tuchów, Zbąszyń, Bełk, Bochnia, Lipnica Murowana). In the case of

36 Cieślińska B., Kształcenie nauczycieli przedszkoli w Polsce w wymiarze instytucjonalnym, Rocznik Towarzystwa Naukowego Płockiego, 2017, nr 9, p. 511.

37 http://www.rymanow-zdroj.pl/materialy/tom06_03.pdf S. Jolanta Bartman, Bł. Edmund Bojanowski prekursorem pedagogiki przedszkolnej i wczesnoszkolnej na ziemiach polskich. Ochronka Św. Józefa w Rymanowie. :Rocznik Rymanowa Zdroju" Tom VI, p. 24

388 (19) "Nasz Rymanów" of August 2002.

39 http://www.szkolalubcza.pl/index.php/patron.html.

40 Gminny Program Rewitalizacji gminy Ryglice na lata 2016-2023 (Ryglice Municipal Revitalisation Programme 2016-23). 
nurseries located in larger cities, the attractive architectural form was conducive to adaptation to contemporary purposes (Bydgoszcz, Anna Scheibler Nursery in Łódź, nurseries in Warsaw).

An example of the harmonious extension and transformation of a nursery building to changing needs, while maintaining the basic function is the building in Szynwałd. The three-storey brick building was quickly expanded and transformed into a women's school. Currently, the function of a kindergarten run by nuns has returned.

The Nałęczów Nursery building after World War II was renovated by the Craftsmen Cooperative of Renovation and Building Services, as a result of which the truss and roofing were partially replaced and the interiors were refreshed. ${ }^{41}$ The nursery served as a kindergarten for over 100 years. In 2001 the kindergarten function was moved from the Nursery to a new building erected at E. Szelburg-Zarembina Street in Nałęczów. The building was later leased and renovated by the Villa Polonia Foundation, it also served as the seat of the Society of Friends of Nałęczów. According to the inhabitants of Nałęczów, this function has grown so strong in the landscape of Nałęczów that it was opted for the building to serve as the Museum of Kindergarten Education and the Nałęczów Museum. ${ }^{42}$ Currently, the "House of Light" is the seat of the Bolesław Prus Museum. ${ }^{43}$ The museum is situated on the outskirts of the main walking routes of patients and tourists, not enjoying special popularity. However, the very fact that the facility retains a public utility function is worth emphasizing.

\section{References}

[1] 110 lat Liceum Plastycznego im. Józefa Chetmońskiego w Natęczowie, wyd. Petit na zlecenie, Liceum Plastycznego im. Józefa Chełmońskiego w Nałęczowie, red. P. Kmieć, Ł. Głowacki, K. Rządowski, J. Ćwiek, Lublin 2013.

[2] Antoniewicz K, Ochronka, 1849, N. Piekary: T. Henetzek.

[3] Bartman J., Bł. Edmund Bojanowski prekursorem pedagogiki przedszkolnej i wczesnoszkolnej na ziemiach polskich. Ochronka Św. Józefa w Rymanowie. Rocznik Rymanowa Zdroju Tom VI, s. 24 za: http://www.rymanow-zdroj.pl/materialy/tom06_03.pdf.

[4] Biernacki M., Cel i zadania Światta, [w:] Zebranie organizacyjne Lubelskiego Towarz. Szerzenia Oświaty p. n. „Światto” odbyte w Lublinie w dniu 23 września 1906 roku, nakład Towarzystwo Światto, 1906, Lublin, s. 4-10.

[5] Butryn S., Natęczów wspomnienia o Żeromskim i gościach kurortu, Wydawnictwo Pro - Info, Lublin 2011, s. 27-28, 34.

[6] Cieślińska B., Kształcenie nauczycieli przedszkoli w Polsce w wymiarze instytucjonalnym, „Rocznik Towarzystwa Naukowego Płockiego", 2017, nr 9, s. 508-526.

[7] Gawarecka, Lubelskie Towarzystwo szerzenia oświaty pod nazwa "Światto" (1906 - 1917), „Rocznik Lubelski” 16, 1973, s. $183-186$.

[8] Goltz A., Ochronki wiejskie, 1860, s. 23.

[9] Kościński, Krok w przeszłość Nałęczowa, reprint 1976 - 2001, Polihymnia Lublin, 2013, s. 34-35.

[10] Mironowicz - Panek M., Działalność lubelskiego Towarzystwa Oświatowego "Światto" w: Ziemiaństwo na Lubelszczyźnie, s. 362.

[11] Prus B., Kroniki Tom II, Warszawa 1953.

[12] Przegaliński A, W kręgu Stanisława Śliwińskiego i nałęczowskiej oświaty rolniczej na przełomie XIX i XX wieku, „Rocznik Lubelski" 35, 2009, s. 139-154.

[13] Puławski A., Materiaty do historii zakładu Leczniczego w Nałęczowie (1807-1907), Nałęczów 1908.

[14] Z Lublina, „Architekt. Pismo o architekturze, budownictwie i przemyśle artystyczny”, z. 3, 1924, s. 30.

[15] Żeromski S., Róża,1909 s. 205.

[16] "Nasz Rymanów” 8 (19) sierpień, 2002.

[17] Archiwum Lubelskiego Wojewódzkiego Konserwatora Zabytków. 